\title{
ARTICLE
}

\section{The Size of the Ecumene of the Mediterranean in Ancient Times}

\author{
Aleksandar Valjarević* \\ University of Belgrade, Faculty of Geography, Studentski Trg 3/III, Belgrade, Serbia
}

\begin{tabular}{l}
\hline ARTICLE INFO \\
\hline Article history \\
Received: 22 June 2020 \\
Accepted: 31 July 2020 \\
Published Online: 30 September 2020 \\
\hline Keywords: \\
Ptolemy's ecumene map \\
Density of settlements \\
Coordinates \\
The Mediterranean \\
Ptolemy \\
Modern and Ptolemy's coordinates
\end{tabular}

\section{Introduction}

$\mathrm{P}$ tolemy (Claudius Ptolemy) is considered to be one of the founders of geography, which was formed in $100 \mathrm{AD}$ in Alexandria, today's Egypt. According to historical resources, Ptolemy lived in the first century AD. Together with Eratosthenes (Eratosthenes), Ptolemy is regarded as the best father of geography because he was the first to introduce the concept of geographic coordinates (longitude and latitude) and the idea of creating some maps using geographical projections. Most of the coordinates of the ecumene, set at that time can be found in the epochal book of Almagest. Ptolemy was the first to present the relation between the geographic longitude and gnomonic projection of the solar declination throughout the

\begin{abstract}
For the purpose of this manuscript, we used the old maps of Europe and of the ecumene, as it was known at the time, in order to establish the ecumene properties, as well as the size of the Mediterranean in the time of Ptolemy. We obtained the coordinates (geographic longitude and latitude) from Ptolemy's map of ecumene of ancient Mediterranean settlements. According to the historical data the coordinates of the Mediterranean ecumene were studied in the 7th century, since the Mediterranean was the centre connecting the civilizations of Europe, Asia and Africa. Although longitudinal and latitudinal errors are large, these coordinates are of great importance for the studies of the past settlements. Today, these settlements are the symbol of civilisation and of human existence. Using the data from 501 settlements overall, we obtained two principal maps of the Mediterranean ecumene with the average density of settlements on the area of $2000 \mathrm{~km} 2$. All Ptolemy's maps, which were used, were of great significance from the scientific point of view, since they made the description of 2000 years old civilization possible. Historically, part of these civilizations, and those formed afterwards, belonged to the Mediterranean.
\end{abstract}

year. The complexity of the equinox lines, in the further context of parallels, begins from the equator. These lines extend in durations of the diurnal light reckoning from the summer solstice. The durations increase by a quarter from 12 to 18 equinox hours by the geographic latitude of $\left(58^{\circ} \varphi\right)$, i. e. by 24 equinox hours on the Arctic Circle $\left(66^{\circ}\right.$ $8^{\prime} 40^{\prime \prime} \varphi$ ). The major problem in establishing the total area of the ancient ecumene is the northernmost point situated at the place of Thule (coordinates: $30^{\circ} 30^{\prime} \lambda, 63^{\circ} 00^{\prime} \varphi$ ). The most probable position of that point has still not been completely confirmed, but most scientists think that this settlement belongs either to Iceland or Greenland. The southernmost point according to Ptolemy's ecumene map had the following coordinates: $60^{\circ} 00^{\prime} \lambda,-20^{\circ} 00^{\prime} \varphi$, near Cartum (in present time Assuan) (Orbis Ptolemai, the map

*Corresponding Author:

Aleksandar Valjarević,

University of Belgrade, Faculty of Geography, Studentski Trg 3/III, Belgrade, Serbia;

Email: aleksandar.valjarevic@pr.ac.rs 
of ecumene). The majority of coordinates we used for the present purpose are from Ptolemy's Geography (III, IV). In order to georeference this old map successfully, we compared it to modern, as for construction and deformations, the most similar projections. The ecumene back then, as well as the whole world, was divided into three continents. To the east, it reached Asia Major, India today, to the south, Ethiopia, south of Libya (part of Ethiopia presented on Ptolemy's ecumene map was called Agisymba), to the west, the bay bordering the Ethiopian Bay in the Western Atlantic Ocean ${ }^{[1]}$. All the countries, as well as the settlement coordinates in the past, belong to the Mediterranean of today in a broader geographic sense; historically and geographically, countries forming the Mediterranean are: Gibraltar, Spain, France, Monaco, Italy, Malta, Slovenia, Croatia, Bosnia and Hezegovina, Montenegro, Albania, Greece, Turkey, Cyprus, Syria, Lebanon, Israel, Egypt, Libya, Tunisia, Algeria, Morocco ${ }^{[2]}$. The rest of the data were taken from (Tabula of Europe) with the settlements in the internal and external parts of the Mediterranean. Ptolemy's first ecumene map was done in simple conic projection. This projection might also be referred to as gnomonic one or shadow projection because its coordinates were determined by using the declination of the Sun. Ancient geographers determined geographic positions using some astronomical phenomena, such as, for instance: star places in the sky, the ratio of the height to the length of the shadow during a year, the longest daytime duration within a year for the same terrestrial position. To the ancient geographers, the most useful star was, certainly, the one observed from the Rhodes and Alexandria. It was Canopus in the Carina constellation ${ }^{[3]}$. Almost all of these coordinates were investigated and the analysis of latitude and longitude was performed by means of GIS analysis and the method of geospace dispersion ${ }^{[4]}$. Between the caps occupied by circumpolar and anticircumpolar constellations, there is a zone defined in the following way

$$
\varphi-90^{0} \leq \delta \leq 90^{0}-\varphi
$$

Then for a star attaining the zenith in its upper culmination it is valid $\delta=\varphi$.

So the coordinates of a point on the Eath's surface (latitude) could also be determined from a lunar eclipse. Two towns where the measuring took place were Arabela and Catagena. The major measuring error between the two towns exceeded 110 in longitude ${ }^{[5]}$. For the further analysis of data, we used Ptolemy's coordinates, and those which were missing were obtained directly from the map after its georeferencing. Most of the coordinates contained errors, so we minimised them using the equation (error is smaller in latitude, larger in longitude). Ptolemy obtained the coordinates as a part of degree measured from the equator which was then relatively precisely determined. The longitude was most likely determined from the prime meridian, then located at $\sim 30^{\circ} .60$ from the Greenwich. It is also known that the settlement positions (their coordinates) have higher precision in the internal Mediterranean; its value being 5 arc minutes. Finally, the total number of Ptolemy's coordinates is 8000,233 of which were taken for the purpose of this manuscript from the regions of Hispania, Italia and large islands near Greece, Asia Minor, Levant and Egypt. The missing coordinates were obtained by means of specially created algorithm wherein the relative error in (longitude) within $\sim 1 * 4$ was taken into account. We also used special tools in GIS in order to determine the coordinates today.

\section{Ptolemy's Simple Conic Projection}

One of the first projections made with precision belongs to Ptolemy. In Ptolemy's conic projection the parallels are given as concentric circles (circle outsides). The meridians are given as straight lines. However, the historical importance of this projection is that it was the first to indicate a given point with the help of a coordinate (longitude, latitude). In constructing the cartographic grid, the prime meridian belonged to the Rhodes parallel $\left(\varphi_{0}\right)$. From the Rhodes parallel all other radii of other coordinates from the map are drawn (see Eq.2).

$\rho_{0}=\operatorname{Rctg} \varphi_{0}$

where $\mathrm{R}$ is the radius of the terrestrial sphere reduced according to the map scale. Arc (arcsecant) of the other parallels starts from the common centre. The radius is equal to that of the standard parallel (see Eq.3).

$\rho=\rho_{0}+R \Delta \varphi$

The angle $(\delta)$ obtained from the meridian grid, as well as the meridian approaching angle, is found by applying the formula for chord length within equilateral triangle. The chord length, as well as the angle between meridians, is calculated by using the following equations (see, Eq.4, Eq.5).

$\frac{\mathrm{d}}{2}=R \operatorname{ctg} \varphi_{0} \sin \frac{\delta}{2}=R \cos \varphi_{0} \sin \frac{\Delta \lambda}{2}$

$\delta=\Delta \lambda \sin \varphi_{0}$

In Ptolemy's conic projection the direction and the 
shape of the prime meridian depends on the direction of its extension. The standard parallel of this projection has preserved the zero deformation only. As the standard parallel becomes more distant, the deformations of lengths, angles, as well as of the areas, enormously increase. At the poles the deformations are infinite. The basic formula for construction of Ptolemy's projection is given in Equation (6).

$$
\begin{gathered}
\delta=\Delta \lambda * \sin \varphi_{0}, \rho_{0}=\mathrm{R} * \operatorname{ctg} \varphi_{0}, \rho=\mathrm{R} * \operatorname{ctg} \varphi_{0}+\mathrm{R}\left(\varphi_{0}-\varphi\right), \\
\rho_{\mathrm{E}}=\mathrm{R} * \operatorname{ctg} \varphi_{0}+\mathrm{R} \varphi_{0}, \mathrm{x}=\mathrm{q}-\rho * \cos \delta, \mathrm{y}=\rho * \sin \delta, \mathrm{n}=1, \\
\mathrm{~m}=\frac{\cos \varphi_{0}-\left(\varphi_{0}-\varphi\right) * \sin \varphi_{0}}{\cos \varphi}, \mathrm{p}=\mathrm{m}, \operatorname{tg}\left(45^{0}+\frac{\omega}{4}\right)=\sqrt{\mathrm{m}}
\end{gathered}
$$

In ths equation $\left(\rho_{\mathrm{E}}\right)$ is the radius of equator projection, $(q)$, is the radius of the parallel, $(n)$ is the linear scale for the parallel direction, $(m)$ is the linear scale for the meridian direction, $(\rho)$ is the area scale, $(\omega)$ is the maximal angle deformation. According to Ptolemy, the end of the cartographic grid is the south geographic tropic which is presented as a circle arc of a length equal to the presentation of the north geographic tropic (parallel of Syene, today Aswan in Egypt). Due to the appearance of deformations, Ptolemy himself corrected the projection so that it is not completely conic in its shape (Figure 1). There are the settlements and their coordinates of the Mediterranean ecumene partly taken from the map of Ptolemy's ecumene [6].

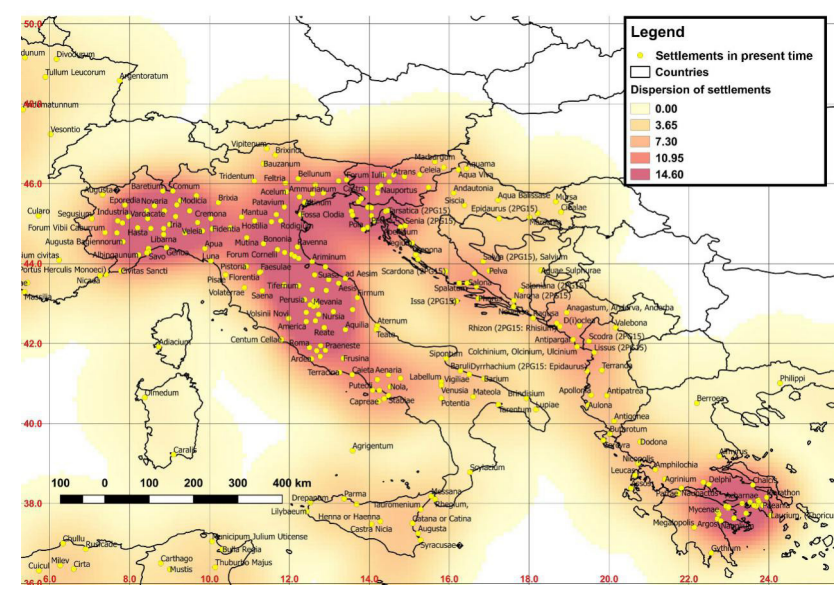

Figure 1. The ecumene as it is today. The coordinates of the settlements from the period of the Roman Empire and Ptolemy are preserved in this presentation

\section{Historical Background of the Mediterra- nean}

The Mediterranean is today a region of diverse sociological, cultural and religious communities. Any determination of its frontiers in the past contributes to a better insight of its present state, but also of its future. Following some theoreticians who minimalise the frontiers, the Mediterranean is bordered by olive dispersion to the north and the south. Following the maximalist definitions, the Mediterranean is given through historical transition zones. In the present paper, the authors are focussed on the Mediterranean within the Roman Empire presented in ${ }^{[7]}$. In the $1^{\text {st }}$ and the $2^{\text {nd }}$ century, the population was partly assimilated by the Roman Empire so that the frontiers of the ancient Mediterranean states were removed, since the Mediterranean economically and culturologically merged into the Roman Empire. Within the Roman Empire the central place of the Mediterranean certainly belonged to the capital Rome, whereas the other parts were regarded as provinces ${ }^{[8]}$. According to the usual standpoint, the past of the Mediterranean is, in fact, the past of its towns or cities ${ }^{[9]}$. Therefore, we also refer to the Mediterranean settlements which were most frequently mentioned in the Roman Empire. A concise and detailed review by James C. Russell gives a definition that within the Roman Empire it is possible to distinguish the Western Mediterranean Italy, Iberia and North Africa - and the Eastern Mediterranean with regions - Greece with the Balkans, Egypt, Asia Minor and Israel ${ }^{[10]}$. Italy with its cultural and religious capital Rome had between 7 and 7.5 million inhabitants then, the other centres being: Neapolis, Capua, Catania, Bologna, i. e. Algeria, Caralis, Panormus and Syracusae on the Balearic islands. The most romanised parts of the Empire comprised following towns: Gades, Tarraco, Cordoba and Carthago-Nova, which had more than 6 million inhabitants (Ibid.,74). The population of Nothern Africa in the $1^{\text {st }}$ and the $2^{\text {nd }}$ century was between 4 and 4.5 million. Important trade and cultural centres were: Tingi, Caesarea, Cirta, Utica, Carthago, Leptis-Magna and Cyrene. Greece with the Balkans, which was positioned between the western and eastern parts of the Roman Empire, had about 5 million inhabitants ${ }^{[11-13]}$. The towns of this Mediterranean part were the most important cultural and social centres, in some of which the first philosophical thought was developed, the most important being: Athens, Corinth, Rhodes, Thessalonica, Salonae and Dyrrhachium. In the eastern parts of the Roman Empire, though they were provinces, the Hellenistic elements survived all the time. The proof is in towns abundantly filled with features of cultural living milieu, cultural heritage, as well as the settlement shape ${ }^{[14-17]}$. On the territory of Egypt, Asia Minor, Syria, Israel, the number of inhabitants was between 20 and 25 million. In that part of the Empire, some of the former Hellenistic towns were transformed into Roman ones. Among the most important urban centres the following should be mentioned: Alexandria and Memphis in 
Egypt, Ephesus and Miletus in Asia Minor, Antioch, Tyre, Palmyra and Hierosolyma in Syria (Figure 2).

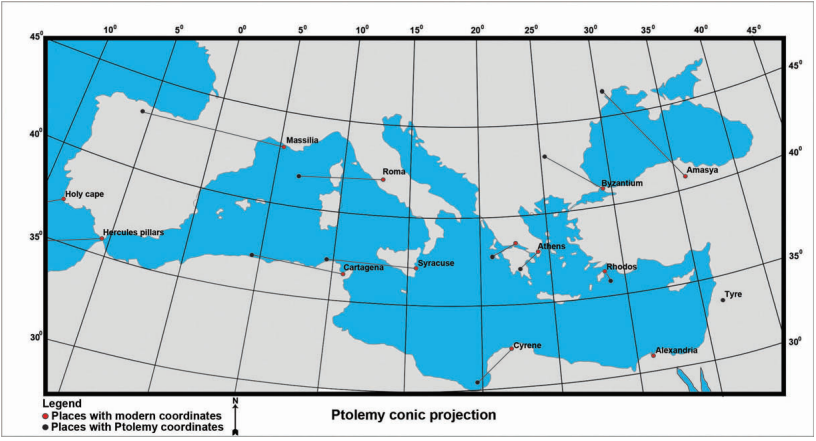

Figure 2. Modern map of the Mediterranean in Ptolemy's conic projection. Comparison of old Ptolemy's coordinates and modern coordinates. Most errors visualized in the direction of parallels

\section{GIS Background Analysis}

Geographic Information System (Abbrev.GIS), and the numerical modelling of geographic data appear as very powerful tools in the calculation and treatment of a large data body. GIS also offers the possibility of redesigning old maps, and by using the interpolation technique and special spatial analysis ordinary kriging (KR) and a special algorithm (IDW), it becomes possible to treat all points (coordinates) from Ptolemy's old maps. In modelling the inner and outer Mediterranean parts, the coordinates of old and new settlements and determining the ecumene of Ptolemy's time all treated geospatial data are used. Ordinary global kriging and Inverse distance weighted (IDW) methods are also used as auxiliary open source QGIS and SAGA (GIS-a) using special extension of Geo-spatial Analyst. Although there are a few other methods, the priority is given to ordinary kriging because it includes autocorrelation or the statistical relationship among the measured points. This method of treating geospatial data unlike the other ones is not based on the distance of measured points only, but it minimises the variance and the standard error between the points of geospace. Settlements of the inner and outer Mediterranean parts are presented on the maps (see Figure1; Figure2). During the data treatment, we included the wellknown settlements from Ptolemy's maps and books and compared them to the present coordinates (see Figure3). The first Mediterranean zone is divided into states of Italy and Greece. The other Mediterranean states are divided and classified depending on the geographic position of the towns. We also determined the approximate date of Ptolemy's projection since the precise dates of modern projections concern the $19^{\text {th }}$ century only. The other coordinates were georeferenced directly from Ptolemy's ecumene map (ecumene). Other sources used for the purpose of data determining were: archaeological localities, historical books, historical archives and old maps. All coordinates, both from Ptolemy's ecumene map and the ones from new maps, are given in the Universal Transverse Mercator projection, after georeferencing. The largest errors are found between the parallels, and the average measured error lies between 80 and 110 (see Figure 3), on the prime Rhodes Meridian being approximately $\sim 1 * 3$, farther from it approximately ${ }^{[17,18]}$. The inner Mediterranean presented on Ptolemy's ecumene map has errors by $40 \%$ less when compared to the outer one ${ }^{[20]}$.

\section{Ecumene in the Ancient Times}

Notwithstanding their incorrectness, the coordinates from Ptolemy's map have an enormous importance. The errors are also due to non-single measuring system; geographic latitude is determined by applying astronomical methods, local times are often discordant. The Alexandria parallel was assumed by Ptolemy to be the prime meridian and also as a referent one (Alexandria $60^{\circ} 30^{\prime}$ ). The known ecumene on Ptolemy's map is given within a small quadrant (see, Figure4). After the treatment of the coordinates of settlements and their dispersion, the highest density of population and towns includes Italy, Greece and Spain. Here the ecumene has preserved the shape by direction of $180^{\circ}$. The border is abruptly deformed from the coast of the Iberian Peninsula and in the east towards India. Among the reasons for this error is also the fact that Ptolemy had no knowledge whether this part of the ecumene was populated. Another theory is in favour of Ptolemy's basing his first conic projection on the Eratosthenes square projection which also gave a similar form of ecumene. The second reason concerns the fact that both Eratosthenes and Ptolemy adopted the prime meridian at the Rhodes. Therefore, the other parallels were drawn concentrically on the maps from this parallel and, as a consequence, the errors increased as being farther from it. The third reason lies in the fact that Ptolemy's second projection (pseudo-conical) had more accurate coordinates than the first one, but he, for reasons known to him only, in presenting the ecumene preferred the first projection. After the data treatment in (GIS), also see (Figure 1), the highest density of settlements occurs in the territory between the Rhodes and Athens, and further in the territory of the Apennine Peninsula and the central parts of the Iberian Peninsula and France. The coordinates which Ptolemy used for the parts of Eastern and Southern Europe differ significantly 
in sources from which they were obtained, concerning their accuracy. Due to the small amount of data taken from the parts of Eastern Europe, the error in coordinates is $10 \%$ higher than in the coordinates from Southern Europe, in terms of geodesy ${ }^{[19]}$.

After GIS analysis, the conclusion is that the lowest density in the Mediterranean in Ptolemy's time was 2.56 settlements per $1000 \mathrm{~km}^{2}$, i. e. in parts with somewhat higher population it was between 2.56 and 5.11. The highest density on the Mediterranean territory was between 7.68 and 10.23 per $1000 \mathrm{~km}^{2}$. In some parts near Rome and Athens, also Alexandria, it was even more than 10.23 settlements per $1000 \mathrm{~km}^{2}$, but this is only $3 \%$ of the total area. In treating the data, one should bear in mind that even Ptolemy himself did not treat all the Mediterranean settlements and, as a consequence, he did not indicate them on the maps. Present Mediterranean settlements which cover the same territories as from Ptolemy's map show some deviations, but the population density is surely higher. The central Mediterranean parts have the highest density of population and settlements. It decreases towards the north and the south. The lowest density of settlements is 3.65 per $1000 \mathrm{~km}^{2}$, in denser parts between 3.65 and 7.30 per $1000 \mathrm{~km}^{2}$. The Mediterranean regions more densely populated are within 7.30 to 10.95 per 1000 $\mathrm{km}^{2}$, for even denser parts within 10.95 to 14.60 per 1000 $\mathrm{km}^{2}$, whereas for $10 \%$ of the area the density of settlements exceeds 14.60 . The first conclusion is that the number of settlements compared to the situation of Ptolemy's time has increased more than 20 times, the second one that there are settlements which existed in Ptolemy's time, but today are known under different names. On the other hand, some settlements have vanished completely from the territory of the Mediterranean during the long period of the history of civilisation (see Figure 3).

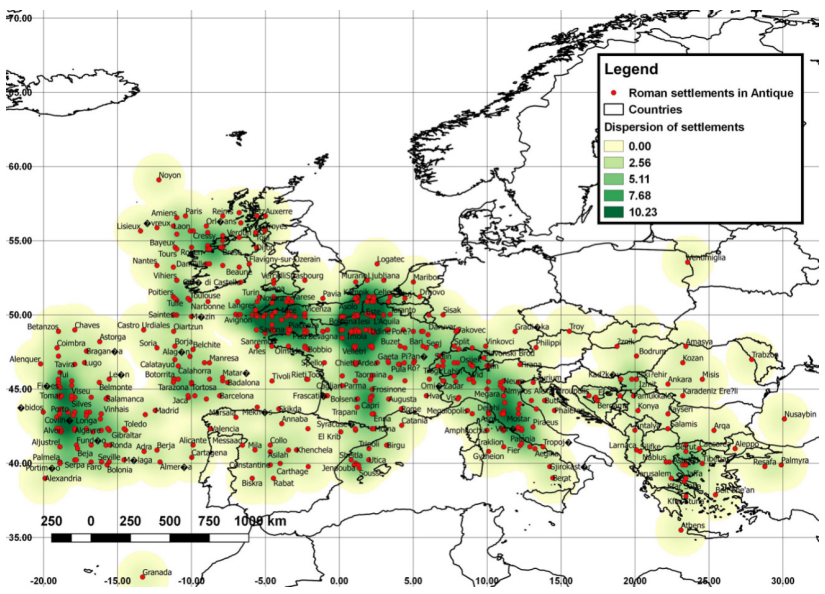

Figure 3. The ecumene as it is today, projected in Universal Transverse Mercator. Settlements given with Ptolemy's coordinates from the period of the Roman Empire

\section{Discussion and Conclusion}

The relationship between terrestrial measurements and astronomical phenomena contributed to the development of ancient geography which developed on the territory of the Mediterranean. Geometric methods and the use of units such as stades and steps made it possible to perform the first direct measurements and to present the results on the maps. For instance, ancient geographer Eratosthenes used his excellent knowledge of astronomy for the purpose of determining the circumference of the Earth, which, according to him, was equal to 252,000 stades $(39,690 \mathrm{~km})$, whereas Ptolemy estimated this circumference to 180,000 stades $(28,350 \mathrm{~km}),(1$ stade was approximately $157.5 \mathrm{~m}$, whereas the Roman stade was approximately $185 \mathrm{~m}$ ). Ptolemy's merit, in addition to the precisely determined geographic position (longitude and latitude), is also the defining of the prime meridian with respect to which the other meridians were determined. Consequently, on the Mediterranean territory for the first time, local times could be applied. Ptolemy then determined the geographic longitude for Alexandria to $60^{\circ} 30^{\prime}$, from the Isle of the Blessed. The bestknown part of the ecumene (Figure 4) is indicated in the quadrant of his ecumene map. It was most densely populated, its shape being similar to a cloak worn in ancient times. This quadrant extended by 1800 westwards to the Iberian coasts and eastwards to the central parts of India. Its southernmost point was on the southern hemisphere reaching the latitude of $-16^{\circ} 25^{\prime}$. It was parallel to the Egyptian town of Meroë. The northernmost point reached Thule, latitude of $63^{\circ} 00^{\prime}$. The main parallel (meridian) divided the outer Mediterranean at Rhodes, longitude of $36^{\circ} 00^{\prime}$. This meridian was also known as a diaphragm or Ionic Equator. This diaphragm divided the ecumene into western and eastern, southern and northern parts. Ptolemy put the central part of the ecumene in the heart of the Mediterranean. The ecumene area inside Mediterranean according to Ptolemy was $72000 \mathrm{x}$ 350000 stades, approximately 62 million $\mathrm{km}^{2}$ (see Figure 4). Another importance of Ptolemy's ecumene map is contained in using, for that time, up-to-date scientific means and techniques such as gnomon, orthographic projection, quadratic-cylindrical projection, pseudo-conic projection, simple conic projection, stereographic projection, stades and others. In the present paper, the comparison of two kinds of geographic data is successfully carried out, one body of data being from Ptolemy's Geography (book), the other body being from his map of ecumene. In determining the area and shape of the Mediterranean ecumene, the fact that the notion of the 
prime parallel - equator was applied for the first time in cartography is kept in mind. Knowing the history of the ancient Mediterranean one can also verify the present positions of past settlements, discover new archaeological localities or describe the history of settlements which no longer exist. Ptolemy's view inside the Mediterranean is almost 2000 years old, and it shows the historical importance of this region. The errors in this projection of Ptolemy, despite their existence, did not reduce the significance of the fact that the settlements were indicated on a map for the first time, by the use of geographic longitude and latitude. Therefore, the Mediterranean was presented realistically for the first time, and after 19 centuries it is possible to note the distribution of settlements by using modern scientific tools like GIS.

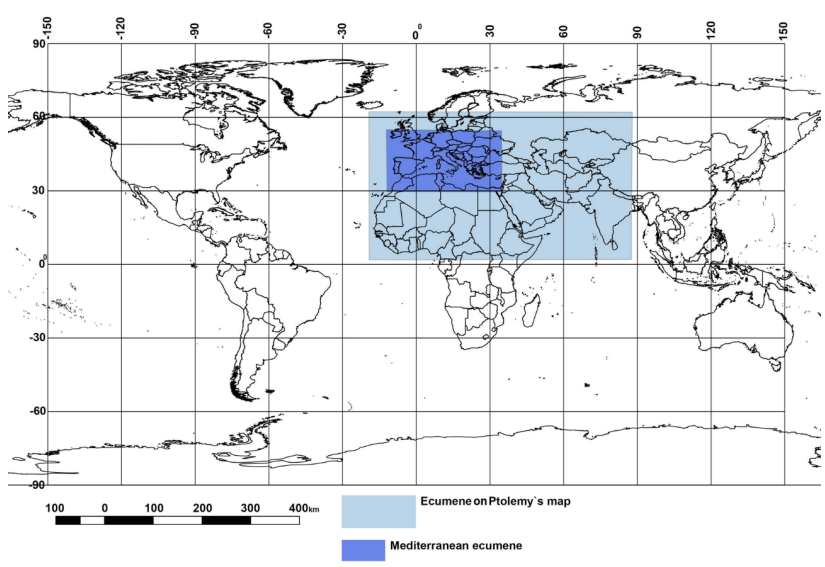

Figure 4. Ptolemy's map of the ecumene comprising the area of Mediterranean in Equirectangular projection

\section{Future Research}

Some authors successfully reconstructed history and climate after the Roman Empire. This pioneering venture established new comparative study called interdisciplinary history. Some authors found strong connection of History and Natural sciences, such as ecology. These principles used geographical, historical and ecological investigation for better conlusions. Also, we found a strong connection between history, geography, cartography, astronomy and mathematical geography and history, with the help of GIS tools. A map is an important means not only in geography, but also in history. Historical cartography is important, and it can always be used in various fields as a referent scientific discipline. Ptolemy's map has been an important historical and geographic source. The distribution of settlements, scattered when observed, can be compared to the distribution of settlements today. After implementing all the Mediterranean settlements from Ptolemy's ecumene map in the data- base and with the help of his epochal Geography, it is possible to determine the Mediterranean population for the period in which the map was made (the $1^{\text {st }}$ and the $2^{\text {nd }}$ century) much more accurately. By applying other scientific disciplines and methods, such as - historical, demographic, culturological, archaeological, medical, etc. - it is possible to obtain more precise data on the life in the Mediterranean in the ancient times.

\section{Disclosure Statement}

No potential conflict of interest was reported by the authors.

\section{Acknowledgments}

The authors are very grateful to the Serbian National Library for providing data, as well as to the Serbian Ministry of Education and Science that supported this work within the project No. III 044006 .

\section{References}

[1] Renou, L. La geographie de Ptolemee. L'Inde Paris, by L. (Foreword), A. Moussa (Foreword), Hans Günter Brauch (Editor), Peter H. Liotta (Editor). Security and Environment in the Mediterranean: Conceptualising Security and Environmental Conflicts, Springer-Verlag Berlin Heidelberg, New York, 2003.

[2] Brauch, G. Urbanization and Natural Disasters in The Mediterranean. Population Growth and Climate Change in the 21st Century, (Chapter 11): Building Safer Cities-The Future of Disaster Risk, 2003, 149164.

[3] Pingree, D. The teaching of the Almagest in Late Antique. Apeiron: A Journal of Ancient Philosophy and Science, 1994, 4: 75-98.

DOI: 10.1515/APEIRON.1994.27.4.75

[4] Scheglov, D. The error in Longitude in Ptolemys Geography Revisited. The Cartographic Journal, 2016, 53: 3-14.

DOI: 10.1179/1743277414Y.0000000098

[5] Raisz, E.. General cartography, McGrawHill Book Company, NewYork, 1995.

[6] Neugebauer, O. The exact science in Antiguiti. London, 1957.

[7] Morelli, V., Salvati, L. Ad Hoc Urban Sprawl in the Mediterranean city. Dispersing a compact tradition, Roma: Edizioni Nuova Cultura, 2010.

[8] Valjarević, A., Živković, D., Božović, R., Tomanović, D., Krsmanović, S., Cvetković, V. Landscape Changes through History Following the Example of the Former Narrow-Gauge Railroad Belgrade ( $\breve{\mathrm{Cu}-}$ 
karica-Obrenovac) Serbia. Journal of Urban History, 2019.

https://doi.org/10.1177/0096144219877882

[9] Leontidou, L. The Mediterranean City in Transition. Cambridge: New York: Cambridge University Press, 2002.

[10] Russell, C. Late Ancient and Medieval Population. Transactions of the American Philosophical Society, 1958, 48:111-152.

DOI: $10.2307 / 1005708$

[11] Gill, N (n.d.). Main Roman Provinces with Their Dates. 2016. Avaiable from http://ancienthistory. about.com/od/romemaps/f/RomanProvinces

[12] Matvejevic, P. Mediterranean. A Cultural Landscape. (M. H. Heim, Trans.). University of California Press, Mediterranean. (n.d.). In Oxford Dictionaries, USA, 1999.

[13] Scheglov, D. Eratosthenes' Contribution to Ptolemy's Map of the World. Imago Mundi: The International Journal for the History of Cartography, 2017, 69:159175.

DOI: http://dx.doi.org/10.1080/03085694.2017.1312 112

[14] Delanty, G. The Historical Regions of Europe: Civilizational Backgrounds and Multiple Routes to Modernity. Historická Sociologie, 2012, 2: 9-24.

[15] Giordano, C. Mediterranean Region. 2016, 5: 1201-
1209.

[16] John, H, Thomas, L. Climate Change during and after the Roman Empire: Reconstructing the Past from Scientific and Historical Evidence. Journal of Interdisciplinary History, 2012, 43:169-220.

DOI: 10.1162/JINH_a_00379

[17] McCormick, M., Ulf Büntgen, M. A., Cane, E., Cook, K. H., Peter J. H., Thomas L, et al. Climate Change during and after the Roman Empire: Reconstructing the Past from Scientific and Historical Evidence. Journal of Interdisciplinary History, 2012, 43:169-220.

DOI: $10.1162 / J I N H \_$a 00379

[18] Relano, F. Against Ptolemy: The significance of the lopes-Pigafetta map of Africa. Imago Mundi: The International Journal for the History of Cartography, 1995, 47(1): 49-66, 1995.

DOI: $10.1080 / 03085699508592813$

[19] Kleineberg, A., Marx, C., Lelgeman, D.. Europa in der Geographie des Ptolemaios Die Entschlüsselung des. Atlas Oikumene. Zwischen Orkney, Gibraltar und den Dinariden, Academic in Wissenschaftliche Buchgesellschaft (WBG), 2012.

[20] Strang, Alastair. The analysis of Ptolemeys Geography, The Cartographic Journal, 1998, 35(1): 27-47. DOI: $10.1179 / 000870498787074074$ 